\title{
Synthesis of novel psoralen analogues and their in vitro antitumor activity
}

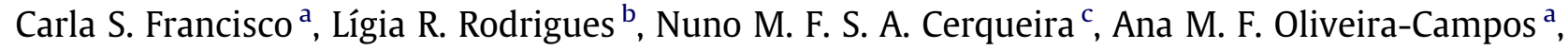 \\ Lígia M. Rodrigues ${ }^{a}$, Ana P. Esteves ${ }^{a, *}$ \\ ${ }^{a}$ Chemistry Centre, School of Sciences, University of Minho, Campus de Gualtar, 4710-057 Braga, Portugal \\ ${ }^{\mathrm{b}}$ IBB-Institute for Biotechnology and Bioengineering, Centre of Biological Engineering, University of Minho, Campus de Gualtar, 4710-057 Braga, Portugal \\ ${ }^{\mathrm{c}}$ REQUIMTE, Faculty of Sciences, University of Porto, Rua do Campo Alegre s/n, 4169-007 Porto, Portugal
}

\section{A R T I C L E I N F O}

\section{Article history:}

Received 27 March 2013

Revised 19 June 2013

Accepted 20 June 2013

Available online 2 July 2013

\section{Keywords:}

Benzofurocoumarins

Benzopsoralen analogues

Antitumor activity

Docking

Computational studies

\begin{abstract}
A B S T R A C T
New tetracyclic benzofurocoumarin (benzopsoralen) analogues were synthesized and their inhibitory effect on the growth of tumor cell lines was evaluated. The human tumor cell lines used were MDA MB231 (breast adenocarcinoma), HeLa (cervix adenocarcinoma) and TCC-SUP (bladder transitional cell carcinoma). The in vitro antitumor activity of the new benzopsoralens was discussed in terms of structure-activity relationship. Molecular docking studies with human-CYP2A6 enzymes were also carried out with the synthesized compounds in order to evaluate the potential of these compounds to interact with the heme group of the enzymes. The results have demonstrated that the linear compounds have the most pronounced activity against tumor cell lines and this might be related to the better accessibility that these compounds have to the active site in relation to the angular ones that have shown in the majority of the cases multiple binding poses in the active site of CYP2A6.
\end{abstract}

() 2013 Elsevier Ltd. All rights reserved.

\section{Introduction}

Psoralens are natural products (linear furocoumarins) present in several plant families, which have been shown to possess a wide spectrum of biological activities including cytotoxic, phytotoxic, photosensitizing, insecticidal, and antibacterial to antifungal effects. ${ }^{1-4}$ Furthermore, psoralens have been suggested as potential therapeutics for the treatment of skin disorders (e.g. vitiligo, leukoderma and psoriasis), ${ }^{5-9}$ cutaneous T-cell lymphoma, ${ }^{10-12}$ autoimmune diseases ${ }^{13,14}$ and several types of cancer. ${ }^{15-24}$

An outstanding feature of psoralens is their ability to intercalate into dsDNA and create covalent cross-links primarily with thymidine residues. ${ }^{1,25}$ Crosslinking proceeds readily under photoactivation and potentially blocks DNA replication and transcription. Furthermore, psoralens are known to interrupt drug metabolism, especially by the inactivation of cytochromes P450 (CYPs); ${ }^{13,26}$ thus the P450 superfamily is suggested as one of the main drug targets. Human CYPs are a family of heme containing enzymes involved in the biotransformation of xenobiotics, as well as endogeneous molecules, and in the bioactivation of carcinogens., 27,28 CYP1A and CYP2B subfamilies are particularly impor-

\footnotetext{
* Corresponding author.

E-mail addresses: carla.iq@gmail.com (C.S. Francisco), lrmr@deb.uminho.pt (L.R. Rodrigues), nscerque@fc.up.pt (N.M.F.S.A. Cerqueira), amcampos@quimica. uminho.pt (A.M.F. Oliveira-Campos), ligiar@quimica.uminho.pt (L.M. Rodrigues), aesteves@quimica.uminho.pt (A.P. Esteves).
}

tant due to their capacity to 'activate' a broad variety of environmental contaminants leading to highly reactive metabolites that react with macromolecules such as proteins, lipids and nucleic acids. ${ }^{29}$ The inhibition of CYP1A1 and CYP1A2 has been implicated in the antigenotoxic mechanism of several furocoumarins, such as bergamottin and naringin..$^{9,30,31}$ Psoralen and xanthotoxin (8-methoxypsoralen) can be oxidized at the furan ring to form a furanoepoxide that binds to CYP2B1. ${ }^{32}$ In addition, xanthotoxin up-regulates CYP1A1 expression. ${ }^{33}$ Psoralen can behave as a general competitor substrate or act as a suicide inhibitor reacting with the heme group of the P450 proteins, consequently inactivating them. ${ }^{26,34}$ Xanthotoxin, bergapten (5-methoxypsoralen) and psoralen were found to act as suicide inactivators of humanCYS2A6 protein in liver microsomes. ${ }^{35}$ Also, bergapten was reported as a suicide inhibitor of human CYP3A4, and xanthotoxin was found to competitively inhibit a variety of drug metabolites catalysed by CYP3A4. ${ }^{36}$

Several research groups are engaged in the synthesis and evaluation of biological properties of psoralen derivatives, ${ }^{37,38}$ including benzopsoralens. ${ }^{39,40}$ Previously in our group some psoralen type compounds were prepared and found to inhibit the in vitro growth of different human tumor cell lines. ${ }^{41,16}$ The angular compounds derived from dibenzofuran showed the most promising results. ${ }^{41 b, 16}$ In the current study, one linear analogue was prepared (compound 1, Fig. 1) and tested. Other compounds, derived from 2-hydroxycarbazole, were also synthesized, one of them 
linear (compound 2, Fig. 1), three others angular (compounds 4-6, Fig. 1) and their biological activity was determined. Furthermore, their binding poses in the active site of human-CYS2A6 enzymes were evaluated by molecular docking studies (see Fig. 2), in order to investigate their potential to interact with the heme group of the enzymes.

\section{Results and discussion}

\subsection{Chemistry}

Compound 1 was prepared, in 27\% yield, from 2-hydroxydibenzofuran and ethyl 3-oxobutanoate by a Pechmann reaction (Scheme 1).

The NMR data are consistent with the proposed structure, namely the proton singlets of the coumarin ring at $\delta(\mathrm{H}) 6.47(\mathrm{H}-$
3) and $2.53\left(\mathrm{CH}_{3}\right)$ and the signal at $\delta(\mathrm{C}) 159.91$ for the $\mathrm{C}=0$ group. The same compound was prepared before, by another approach. $^{42}$ The melting point given in the literature is lower $\left(200^{\circ} \mathrm{C}\right)$ than that for our compound $\left(247-249^{\circ} \mathrm{C}\right)$. The author describes the sample as an orange red powder and the coloured impurities may be the reason why its melting point is much lower than in our case.

Compound $\mathbf{2}$ was synthesized by the same method starting from 2-hydroxycarbazole, with a 33\% yield. In the ${ }^{1} \mathrm{H}$ NMR spectrum showed the characteristic signals for compound 2, including the expected singlets at $\delta(\mathrm{H}) 8.57(\mathrm{H}-5)$ and $7.38(\mathrm{H}-11)$.

The remaining compounds were obtained from 2-hydroxy- $9 H$ carbazole-1-carbaldehyde 3 (Scheme 2 and 4-6) which was prepared in low yield (5\%) by Reimer-Tiemann formylation of 2-hydroxycarbazole. The formation of this product was confirmed by ${ }^{1} \mathrm{H}$ NMR data, where the aldehyde proton appeared at $\delta(\mathrm{H})$<smiles>Cc1cc(=O)oc2cc3c(cc12)oc1ccccc13</smiles>

1<smiles>Cc1cc(=O)oc2cc3[nH]c4ccccc4c3cc12</smiles>

2<smiles>O=c1ccc2c(ccc3c4ccccc4[nH]c23)o1</smiles>

4<smiles>CCOC(=O)c1cc2c(ccc3c4ccccc4[nH]c23)oc1=O</smiles>

5<smiles>O=C(O)c1cc2c(ccc3c4ccccc4[nH]c23)oc1=O</smiles>

6

Figure 1. Structures of the prepared compounds.
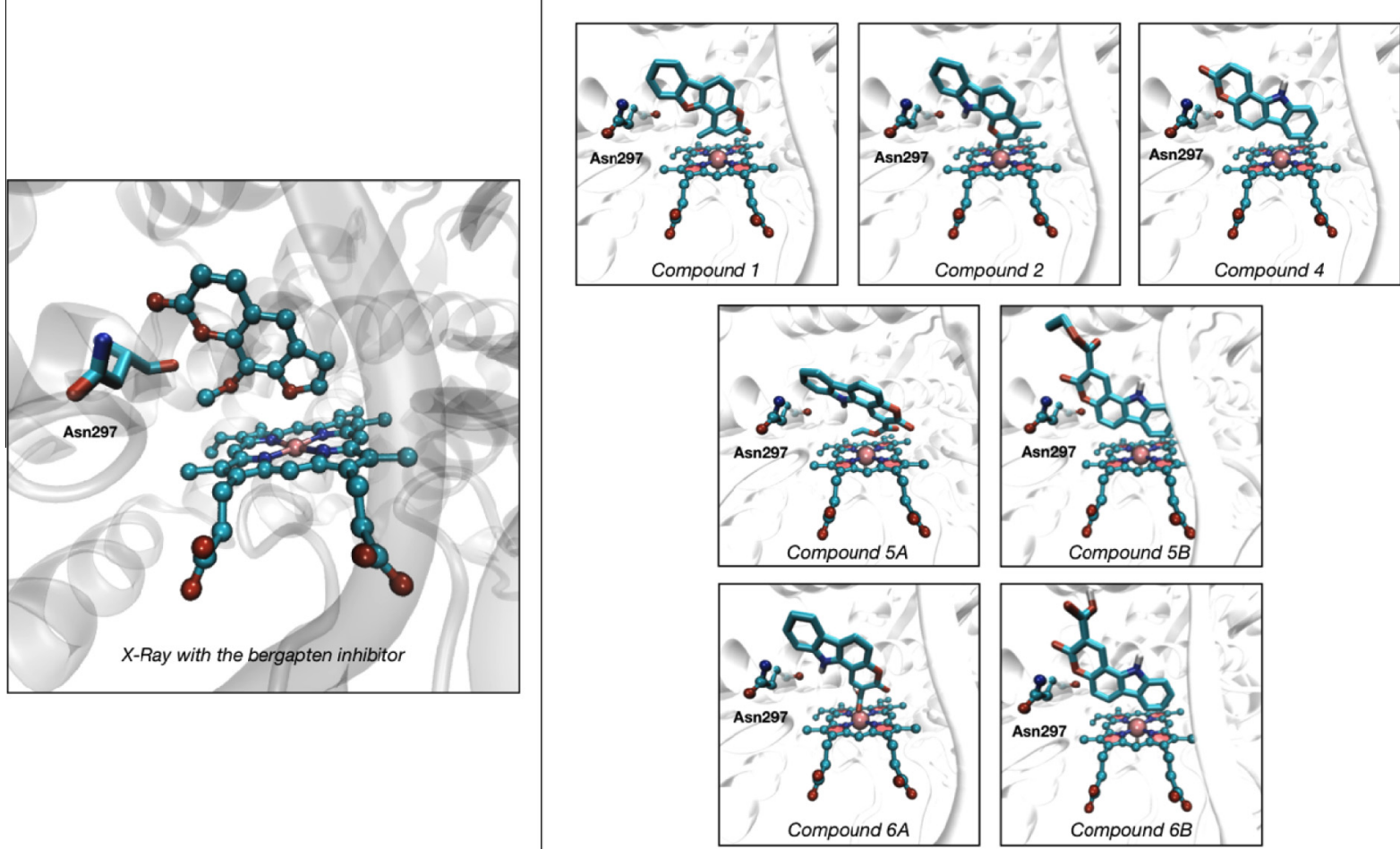

Molecular Docking Complexes

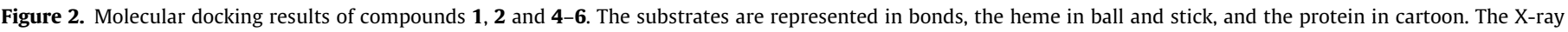
structure with bergapten bound in the active site has the PDB code $1 \mathrm{Z11}$. 


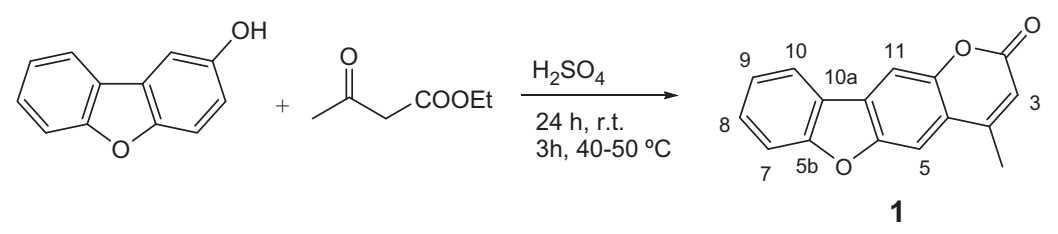

Scheme 1. Preparation of the compound $\mathbf{1 .}$

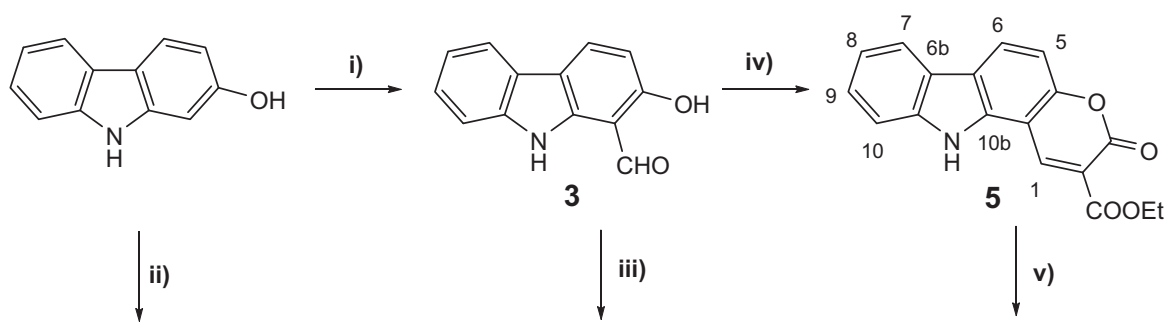

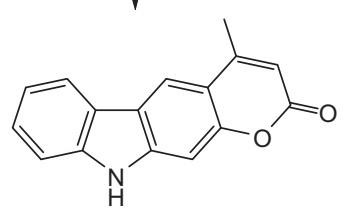

2

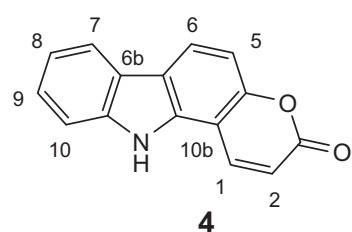

4

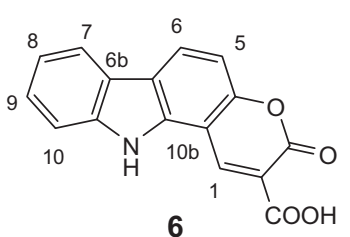

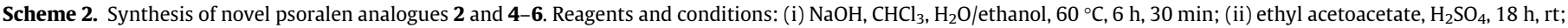
(iii) carbethoxymethylene-triphenylfosforane, $\mathrm{N}, \mathrm{N}$-diethylaniline, $130^{\circ} \mathrm{C}, 30 \mathrm{~h}$; (iv) piperidine, AcOH, diethylmalonate, ethanol, $90^{\circ} \mathrm{C}, 5 \mathrm{~h}$; $(\mathrm{v}) \mathrm{NaOH}$, ethanol, $60^{\circ} \mathrm{C}, 4 \mathrm{~h}$.

10.67 ppm, and $\mathrm{H}-4$ and $\mathrm{H}-3$ at 8.27 and 6.85 , respectively, as doublets $(J=8.7 \mathrm{~Hz})$.

Compound 4 was prepared from the 2-hydroxy-9H-carbazole1 -carbaldehyde, 3 , in $27 \%$, by a Wittig reaction followed by closure to give the pyranone ring. The appearance of two new doublets in the NMR at $\delta(\mathrm{H}) 8.53$ and $6.48 \mathrm{ppm}$ for $\mathrm{H}-1$ and $\mathrm{H}-2$, respectively, agree with the structure.

Reaction of the same aldehyde with diethylmalonate (Scheme 2) gave the pyranocarbazole $\mathbf{5}$, with $38 \%$ yield. The NMR data were consistent with the proposed structure, namely the singlet at $9.26 \mathrm{ppm}$ for $\mathrm{H}-1$ and the signals for the ester group. Basic hydrolysis of the ester $\mathbf{5}$ gave the corresponding acid derivative $\mathbf{6}$ in quantitative yield.

\subsection{Antiproliferative effect on human cancer cell lines}

The ability of the compounds $\mathbf{1 , 2}$ and 4-6 to inhibit the in vitro growth of MDA MB231, HeLa and TCC-SUP cell lines was evaluated and the results, given in concentrations that were able to cause $50 \%$ of cell growth inhibition (GI50), are summarized in Table 1.

A great antiproliferative activity was observed for all the compounds even at the minimum concentration tested $(0.5 \mu \mathrm{M})$. Compound $\mathbf{1}$ was found to be the most active against MDA MB231 and

Table 1

Antiproliferative effect of the studied compounds on human cancer cell lines

\begin{tabular}{llll}
\hline \multirow{2}{*}{ Compound } & \multicolumn{3}{l}{ Inhibition of cancer cell lines GI50 $(\mu \mathrm{M})$} \\
\cline { 2 - 4 } & MDA MB231 & HeLa & TCC-SUP \\
\hline $\mathbf{1}$ & $0.060 \pm 0.002$ & $0.035 \pm 0.001$ & $0.041 \pm 0.007$ \\
$\mathbf{2}$ & $0.078 \pm 0.009$ & $0.042 \pm 0.005$ & $0.066 \pm 0.005$ \\
$\mathbf{4}$ & $0.230 \pm 0.019$ & $0.046 \pm 0.006$ & $0.027 \pm 0.009$ \\
$\mathbf{5}$ & $0.413 \pm 0.031$ & $0.037 \pm 0.003$ & $0.030 \pm 0.004$ \\
$\mathbf{6}$ & $0.265 \pm 0.027$ & $0.047 \pm 0.008$ & $0.018 \pm 0.003$ \\
\hline
\end{tabular}

${ }^{a}$ Data are expressed as average \pm S.D. of three independent experiments with four replicates per concentration in each experiment.
HeLa cells, while for TCC-SUP cells, the compound that showed a higher antiproliferative effect was compound $\mathbf{6}$, although similar to compounds $\mathbf{4}$ and $\mathbf{5}$. These results are in accordance with a number of studies that demonstrate the antiproliferative potential of furocoumarins against several cancer cell lines. ${ }^{17,19,43,44}$

\subsection{Molecular docking}

The enzymes from the cytochrome P450 family are involved in the metabolism of several pharmaceuticals, carcinogens, and a large number of coumarin-type alkaloids. ${ }^{45,46}$ Regarding the nature of this work, CYP2A6 is of particular interest since it has been reported to metabolize indoles, as well as several coumarin analogues. $^{47,48}$ For instance, bergapten is a potent inhibitor of CYP2A6 and contributes to cancer cell death and increased sensitivity to chemotherapy in several types of cancer, ${ }^{49,21}$ in vitiligo and psoriasis diseases. ${ }^{5,38,50}$ The antiproliferative effect of bergapten has been demonstrated on several cancer cell lines, including B16F10 (melanoma cells), gastric adenocarcinoma (MK-1), breast cancer (MCF-7 and T47D), and hepatocellular carcinoma. ${ }^{17,19,21,49,51}$ Likewise, bergapten's cytotoxic effect was shown against HeLa ${ }^{51,52}$ and MDA MB 231 19,43,44 cell lines, which are the ones under study in the present work. To date, no study has been reported on bergapten effects against TCC-SUP cells. Bergapten has a similar scaffold to the new tetracyclic coumarin derivatives that are studied in this work and only differ in the group that is attached to the coumarin ring, that is, it has a pyrrole instead of a furan ring attached to the coumarin. This signifies that the novel tetracyclic benzofurocoumarin analogues, described here, are good candidates to act as potential targets of this enzyme.

The co-crystallized X-ray structure of bergapten in CYP2A6 (PDB code 1Z11) reveals that the substrate fits very well in the narrow binding site. The active site is formed by a cluster of phenylalanine residues (Phe107, Phe111, Phe108, Phe209 and Phe480) that line the 'roof' of the active site and by the presence of a single polar residue, Asn297 (Fig. 2). It is suggested that Asn297 influences sub- 
strate orientation, and metabolism, and therefore might be critical for substrate recognition and binding. ${ }^{53-55}$ Indeed, mutations of this residue often lead to dramatic changes in the kinetics of the reaction that is catalysed by this enzyme. ${ }^{56}$

The molecular docking results undertaken in this study have shown that all the studied compounds bind in the same region of the protein nearby the heme and similarly to what is observed with the bergapten inhibitor in the X-ray structure $1 \mathrm{Z11}$ (Fig. 2). The molecular docking results with compounds 1, 2 and 4 have only provided one binding pose, whereas compounds $\mathbf{5}$ and $\mathbf{6}$ have systematically provided two similar binding poses. This effect seems to be related with the presence of the bulky ester groups attached to $\mathrm{C}-3$ of the coumarin ring that influences the binding mode of these compounds. Interestingly compound $\mathbf{4}$, which has the same scaffold of these two compounds but without any group attached to $\mathrm{C}-3$ of the coumarin ring has only one binding position. The binding poses of compounds 4, 5 (solution B) and $\mathbf{6}$ (solution B) are the closest ones to that observed with the bergapten inhibitor, in which the $\mathrm{C}=0$ group interacts very closely with Asn297 (3.15 $\AA$ ) and carbon C-9 points towards the iron ion of the heme co-factor (3.62 $\AA$ ). The other binding position of compounds 5 and 6 ( $5 \mathrm{~A}$ and $6 \mathrm{~A}$ ) have the $\mathrm{NH}$ group pointing towards Asn297 (2.45 and $3.65 \AA$, respectively) and the groups that are attached to carbon C-3 interacting very closely to the iron ion (2.19 and $2.55 \AA$, respectively). Regarding the antiproliferative effect on human cancer cell lines, compounds $\mathbf{5}$ and $\mathbf{6}$ are in the majority of cases worse inhibitors in relation to the other studied compounds, with the exception of the TCC-SUP cell-lines. Compound $\mathbf{4}$ systematically shows better or comparable results in most cell lines, when compared with compounds $\mathbf{5}$ and $\mathbf{6}$. This suggests that in the latter cases, the worst inhibitory potency can be related with the lack of accessibility to the active site, due to the presence of bulky groups attached to the coumarin moiety and/or the competitive binding mode that was observed.

The compounds $\mathbf{1}$ and $\mathbf{2}$ have the same scaffold and differ only in the nature of the system that is attached to the coumarin moiety, that is, a benzofuran or an indole, respectively. The docking results have only shown one binding pose and it closely resembles what is observed with one of the solutions of compounds $\mathbf{5}$ and 6 (solutions $5 \mathrm{~A}$ and $6 \mathrm{~A}$ ), that is, with the $\mathrm{C}=0$ group of the coumarin moiety interacting very closely with the iron ion of the heme cluster, instead of with Asn297 (2.3 $\AA$ and $2.4 \AA$, respectively). However, the results of the antiproliferative effect of the linear 1 and 2 are better than the compounds 4-6. This might be related with the better accessibility of these compounds to the active site in relation to the other ones. The only exception refers to the celllines TCC-SUP in which the angular compounds $\mathbf{4 - 6}$ gave better results than the linear ones. It is important to notice that in the case of TCC-SUP cells, the GI50 values obtained were very low and similar among each other for compounds 4-6, thus the differences observed are not statistically significant, that is, all the compounds performed equally well in inhibiting the cancer cells proliferation.

The results also indicate that with the exception of the TCC-SUP cells, compound $\mathbf{1}$ has better inhibitory potency than compound $\mathbf{2}$. Taking into account the similarity between their structures, these results suggest that the presence of the pyrrole ring instead of the furan fused to the coumarin moiety tend to decrease the inhibitory efficiency of these compounds. This is in line with all the other pyrrole derivatives that show lower inhibitory properties in the majority of the studied cell lines.

\section{Conclusions}

Four new tetracyclic benzopsoralen analogues were synthesized and their biological activity tested. All the compounds were found to significantly inhibit the proliferation of three human tumor cell lines, which we hypothesize to be mainly associated with the ability that these compounds present to inhibit CYP2A6.

The molecular docking results showed two types of binding poses in all the studied compounds. Compounds $\mathbf{1}$ and $\mathbf{2}$ bind to the active site with the carbonyl group of the coumarin moiety pointing towards to the heme cofactor. This is only possible because of their linear shape that allows them to interact very closely with the iron of the heme (average distance of $2.2 \AA$ ).

In compounds 4-6, the carbonyl group of the coumarin moiety interacts very closely with Asn297 residue through a hydrogen bond. Such binding pose is very similar to what is observed with bergapten (in the bound X-ray structure with the PDB code $1 \mathrm{Z11}$ ) in which the $\mathrm{NH}$ group of the indole ring was found to be responsible for establishing a similar interaction (compounds 4 6). However, these compounds do not interact very closely with the heme cofactor as it is observed with compounds $\mathbf{1}$ and $\mathbf{2}$ (average distance of $3.1 \AA$ ).

The molecular docking have also shown that compounds $\mathbf{5}$ and $\mathbf{6}$ have another binding pose in the active site that is very similar to the one that was obtained for compounds $\mathbf{1}$ and $\mathbf{2}$ (but not so close to the heme co-factor-average distance of $2.9 \AA$ ). These results suggest that the presence of bulkier groups at position 2 and 3 of the coumarin moiety preclude or difficult the binding pose of these compounds in the active site and to acquire a similar orientation in relation to what is found with bergapten. The only compound where this effect is not observed is with compound $\mathbf{4}$ that does not contain any substituent on the coumarin moiety. This suggests that the presence of bulkier groups in the coumarin moiety may be a preponderant factor for the different binding poses of these compounds as compared to what is observed with bergapten. Interestingly, these compounds are the ones whose binding position is closer to the heme cofactor and therefore more prone to interact with it.

The comparison of the binding pose of the compounds 1, 2 and 4-6 in the active site of CYP2A6 and the in vitro antitumor activity of the studied compounds clearly show that the linear ones, in particular the compound $\mathbf{1}$, present the most pronounced activity against tumor cell lines except for TCC-SUP. The molecular docking results suggest that the inhibitory efficiency of the linear compounds is related to the better accessibility that these compounds have to the active site in relation to the angular ones.

The results gathered in the current study demonstrate the reactivity of the new psoralen analogues with CYP2A6, an enzyme that has been related with the bioactivation of carcinogens. Therefore, these novel compounds present a high potential as antitumor agents.

\section{Experimental}

\subsection{Chemistry}

Melting points were determined on a Gallenkamp melting point apparatus and are uncorrected. ${ }^{1} \mathrm{H}$ NMR $(300 \mathrm{MHz})$ and ${ }^{13} \mathrm{C}$ NMR (75.4 MHz) spectra were recorded on a Varian Unity Plus Spectrometer at $298 \mathrm{~K}$ or on a Bruker Avance III 400 spectrometer (400 MHz for ${ }^{1} \mathrm{H}$ and $100.6 \mathrm{MHz}$ for ${ }^{13} \mathrm{C}$ ). Chemical shifts are reported in ppm relative to solvent peak or TMS; coupling constants $J$ are given in Hz. Double resonance, HMQC (heteronuclear multiple quantum coherence) and HMBC (heteronuclear multiple bond correlation) experiments were carried out for complete assignment of ${ }^{1} \mathrm{H}$ and ${ }^{13} \mathrm{C}$ signals in the NMR spectra. High-resolution mass spectra (EI-TOF or ESI) were obtained on a Waters-Micromass Autospec M. or on a Bruker FTMS APEXIII spectrometer, respectively. Elemental analyses were performed on a Leco CHNS-932 instrument. 
TLC was carried out on plates coated with silica gel $60 \mathrm{~F}_{254}$. Column chromatography was performed on silica gel (70-230 or 230400 mesh). Light petroleum refers to the fraction boiling in the range $40-60{ }^{\circ} \mathrm{C}$.

\subsubsection{4-Methyl-2H-benzofuro[2,3-g]chromen-2-one (1)}

A mixture of 2-hydroxybenzofuran $(0.38 \mathrm{~g}, 2.0 \mathrm{mmol})$, ethyl acetoacetate $(0.48 \mathrm{~mL}, 4.0 \mathrm{mmol})$ and chilled concd $\mathrm{H}_{2} \mathrm{SO}_{4}(3 \mathrm{~mL})$ was stirred at $\mathrm{rt}$ for $24 \mathrm{~h}$ and further $3 \mathrm{~h}$ at $40-50{ }^{\circ} \mathrm{C}$. After cooling the mixture was poured over crushed ice and the beige solid formed was filtered and dried $(0.135 \mathrm{~g}, 0.54 \mathrm{mmol}, 27 \%) . \mathrm{Mp}$ 247-249 ${ }^{\circ} \mathrm{C}$ (lit. ${ }^{42} 200{ }^{\circ} \mathrm{C}$ ). ${ }^{1} \mathrm{H}$ NMR (400 MHz, DMSO-d 6 ): $\delta 8.25$ (dd, $J=8.1,1.2 \mathrm{~Hz}, \mathrm{H}-10$ ), 8.22 (s, H-11), 8.10 (s, H-5), 7.75 (dd, $J=9.3,0.9 \mathrm{~Hz}, \mathrm{H}-7), 7.62(\mathrm{td}, J=7.5,1.2 \mathrm{~Hz}, \mathrm{H}-8), 7.45$ (td, $J=8.1$, $1.2 \mathrm{~Hz}, \mathrm{H}-9), 6.47$ (s, H-3), $2.53\left(\mathrm{~s}, \mathrm{CH}_{3}\right)$ ppm. ${ }^{13} \mathrm{C} \mathrm{NMR}$ (100.6 MHz, DMSO-d $): \delta 159.91(\mathrm{C}=0), 157.10$ (C-6a), 153.36 (C4), 151.73 (C-5a), 149.35 (C-11a), 129.42 (C-8), 126.98 (C-10b), 123.50 (C-9), 122.82 (C-10a), 122.38 (C-10), 119.09 (C-4a), 114.29 (C-3), 111.96 (C-7), 108.38 (C-11), 107.139 (C-5), 18.57 $\left(\mathrm{CH}_{3}\right)$ ppm. HR-(EI-TOF)-MS: calcd for $\mathrm{C}_{16} \mathrm{H}_{10} \mathrm{O}_{3}{ }^{+} \mathrm{m} / \mathrm{z} 250.0630$; found: 250.0638 .

\subsubsection{4-Methylpyrano[2,3-b]carbazol-2(10H)-one (2)}

Ethyl acetoacetate $(0.16 \mathrm{~mL}, 1.31 \mathrm{mmol})$ was added to a solution of 2-hydroxycarbazole $(0.16 \mathrm{~g}, 0.87 \mathrm{mmol})$ in ethyl acetate. The reaction mixture was slowly added to chilled conc $\mathrm{H}_{2} \mathrm{SO}_{4}$ $(1.6 \mathrm{~mL})$ and stirred at $\mathrm{rt}$ for $18 \mathrm{~h}$. After pouring over crushed ice a brown solid separated and this was filtered and washed with $2 \mathrm{M} \mathrm{NaOH}$ solution. Purification by $\mathrm{CC}\left(\mathrm{SiO}_{2}\right.$, light petroleum/ethyl acetate) yielded the product as a beige solid $(0.072 \mathrm{~g}, 0.29 \mathrm{mmol}$; 33\%). Mp 249-251 ${ }^{\circ} \mathrm{C} .{ }^{1} \mathrm{H}$ NMR (300 MHz, DMSO- $\left.d_{6}\right): \delta 11.62(\mathrm{~s}$, $\mathrm{NH}$ ), 8.57 (s, H-5), 8.23 (d, $J=7.8 \mathrm{~Hz}, \mathrm{H}-9$ ), 7.45 (td, $J=8.1,1.2 \mathrm{~Hz}$, $\mathrm{H}-7$ ), 7.51 (d, $J=8.1 \mathrm{~Hz}, \mathrm{H}-6), 7.38$ (s, H-11), 7.22 (td, $J=8.1$, $1.2 \mathrm{~Hz}, \mathrm{H}-8), 6.24$ (s, H-3), $2.57\left(\mathrm{~s}, \mathrm{CH}_{3}\right)$ ppm. ${ }^{13} \mathrm{C} \mathrm{NMR}(75.4 \mathrm{MHz}$, DMSO- $\left.d_{6}\right): \delta 160.59(\mathrm{C}=0), 154.36$ (C-4), 152.11 (C-11a), 141.98 (Cq), 140.89 (Cq), 126.27 (C-7), 122.20 (Cq), 120.60 (C-9), 120.27 (Cq), 119.55 (C-8), 117.21 (C-5), 112.49 (C-4a), 111.22 (C-6), 110.48 (C-3), 97.16 (C-11), $18.68\left(\mathrm{CH}_{3}\right)$ ppm. HR-(EI-TOF)-MS: calcd for $\mathrm{C}_{16} \mathrm{H}_{11} \mathrm{NO}_{2}{ }^{+} \mathrm{m} / \mathrm{z} 249.0790$; found: 249.0792 .

\subsubsection{2-Hydroxy-9H-carbazole-1-carbaldehyde (3)}

A mixture of 2-hydroxycarbazole $(0.20 \mathrm{~g}, 1.09 \mathrm{mmol}), \mathrm{H}_{2} \mathrm{O} /$ EtOH (9:1) $(6 \mathrm{~mL}), \mathrm{NaOH}(0.40 \mathrm{~g}, 10.0 \mathrm{mmol})$ and $\mathrm{CHCl}_{3}(0.48 \mathrm{~mL})$ was heated at $60{ }^{\circ} \mathrm{C}$ for $5.5 \mathrm{~h}$. After cooling the reaction mixture was extracted with EtOAc $(3 \times 5 \mathrm{~mL})$ and the combined organic layers were dried $\left(\mathrm{MgSO}_{4}\right)$, filtered and the solvent evaporated to dryness. A yellow solid was obtained and purified by $\mathrm{CC}\left(\mathrm{SiO}_{2}\right.$, light petroleum/diethyl ether, gradient, $100 \rightarrow 70 \%)(9.7 \mathrm{mg}, 0.05 \mathrm{mmol}$, 5\%). Mp 219-223 ${ }^{\circ} \mathrm{C}$ (lit. ${ }^{41 \mathrm{C}} 219-220{ }^{\circ} \mathrm{C}$ ). ${ }^{1} \mathrm{H}$ NMR (300 MHz, acetone- $\left.d_{6}\right): \delta 11.15$ (br s, NH), $10.67(\mathrm{~s}, \mathrm{CHO}), 10.30$ (br s, OH), 8.27 (d, $J=8.7 \mathrm{~Hz}, \mathrm{H}-4$ ), 8.06 (dd, $J=8.4,1.2 \mathrm{~Hz}, \mathrm{H}-5$ ), 7.70 (dd, $J=7.8$, $1.2 \mathrm{~Hz}, \mathrm{H}-8$ ), 7.39 (td, $J=7.8,1.2 \mathrm{~Hz}, \mathrm{H}-7), 7.24$ (td, $J=7.8,1.2 \mathrm{~Hz}$, $\mathrm{H}-6), 6.85$ (d, $J=8.7 \mathrm{~Hz}, \mathrm{H}-3) \mathrm{ppm} .{ }^{13} \mathrm{C}$ NMR (100.6 MHz, acetone$\left.d_{6}\right): \delta 191.03$ (CHO), 161.68 (C-2), 140.90 (C-8a), 140.60 (C-5a), 129.70 (C-4), 125.63 (C-7), 123.35 (C-4b), 120.94 (C-6), 119.96 (C-5), 117.74 (C-4a), 112.42 (C-8), 108.66 (C-3), 108.20 (C-1) ppm. Anal. calcd for $\mathrm{C}_{13} \mathrm{H}_{9} \mathrm{NO}_{2} .{ }_{1}{ }_{4} \mathrm{H}_{2} \mathrm{O}: \mathrm{C}, 72.37 ; \mathrm{H}, 4.44 ; \mathrm{N}, 6.49$; found: $\mathrm{C}, 72.72 ; \mathrm{H}, 4.30 ; \mathrm{N}, 6.57$.

\subsubsection{Pyrano[3,2-a]carbazol-3(11H)-one (4)}

Carbethoxymethylenetriphenylphosphorane $(0.22 \mathrm{~g}, 0.63 \mathrm{mmol})$ was added to a solution of 2-hydroxy-9H-carbazole-1-carbaldehyde $3(0.094 \mathrm{~g}, 0.45 \mathrm{mmol})$ in $N, N$-diethylaniline $(2 \mathrm{~mL})$ and the mixture was refluxed for $30 \mathrm{~h}$. After cooling, water $(20 \mathrm{~mL})$ was added and the solution washed with $\mathrm{Et}_{2} \mathrm{O}(4 \times 10 \mathrm{~mL})$. The organic layer was extracted with $5 \% \mathrm{HCl}(5 \times 10 \mathrm{~mL})$, dried $\left(\mathrm{MgSO}_{4}\right)$ and concentrated. A brown oil was obtained which was purified by preparative layer chromatography (light petroleum/ethyl acetate, $1: 1)$, yielding a light brown solid (0.027 g, $0.12 \mathrm{mmol} ; 27 \%) \mathrm{Mp}$ 259-262 ${ }^{\circ} \mathrm{C} .{ }^{1} \mathrm{H}$ NMR (400 MHz, acetone- $\left.d_{6}\right): \delta 11.21$ (br, s, NH), 8.53 (d, $J=9.6 \mathrm{~Hz}, \mathrm{H}-1$ ), 8.33 (d, J=8.8 Hz, H-6), 8.17 (d, $J=7.6 \mathrm{~Hz}, \mathrm{H}-7), 7.60$ (d, $J=8.0 \mathrm{~Hz}, \mathrm{H}-10), 7.45$ (t, $J=8.8 \mathrm{~Hz}, \mathrm{H}-9$ ), 7.29 (t, $J=8.0 \mathrm{~Hz}, \mathrm{H}-8), 7.17$ (d, $J=9.4 \mathrm{~Hz}, \mathrm{H}-5), 6.48$ (d, $J=9.6 \mathrm{~Hz}$, $\mathrm{H}-2)$ ppm. ${ }^{13} \mathrm{C}$ NMR $\left(100.6 \mathrm{MHz}\right.$, acetone- $\left.d_{6}\right): \delta 160.89$ (C-3), 154.35 (C-4a), 141.05 (C-10a), 139.60 (C-1), 137.06 (C-6b), 126.39 (C-9), 124.68 (C-6), 123,68 (C-10b), 120.88 (C-8), 120.71 (C-7), 120.06 (C-6a), 115.32 (C-2), 112.09 (C-10), 108.81 (C-5), 105.11 (C-4b) ppm. HR-(EI-TOF)-MS: calculated for $\mathrm{C}_{15} \mathrm{H}_{9} \mathrm{NO}_{2}{ }^{+}$ $\left(\mathrm{M}^{+}\right) \mathrm{m} / \mathrm{z}$ 236.0636; found: 235.0633. Anal. calcd for $\mathrm{C}_{15} \mathrm{H}_{9} \mathrm{NO}_{2}$ $1 / 4 \mathrm{H}_{2} \mathrm{O}$ : C, 75.14; H, 3.89; N, 5.84; found: C, 75.08; H, 4.14; N, 5.71.

\subsubsection{Ethyl 3,11-dihydro-3-oxopyrano[3,2-a]carbazole-2- carboxylate (5)}

Diethylmalonate $(60 \mu \mathrm{L})$ and 2-hydroxy-9H-carbazole-1-carbaldehyde $3(0.059 \mathrm{~g}, 0.28 \mathrm{mmol})$ in EtOH $(9 \mathrm{~mL})$ were added to a solution of piperidine ( 3 drops) and acetic acid (3 drops) in EtOH $(1 \mathrm{~mL})$. The mixture was refluxed for $5 \mathrm{~h}$ and after evaporation a red oil was obtained. Purification by flash chromatography $\left(\mathrm{SiO}_{2}\right.$, light petroleum/diethyl ether, gradient, $100 \rightarrow 70 \%$ ) afforded a yellow solid $(0.033 \mathrm{~g}, 0.11 \mathrm{mmol}, 38 \%)$. Mp 198-201 ${ }^{\circ} \mathrm{C}$ (lit. ${ }^{41 \mathrm{c}} 211-$ $212{ }^{\circ} \mathrm{C}$ ). ${ }^{1} \mathrm{H}$ NMR $\left(400 \mathrm{MHz}\right.$, acetone- $d_{6}$ ): $\delta 11.48$ (br s, NH), 9.26 (s, H-1), 8.46 (d, $J=8.4 \mathrm{~Hz}, \mathrm{H}-6), 8.19$ (d, $J=8.0 \mathrm{~Hz}, \mathrm{H}-7), 7.65$ (d, $J=8.4 \mathrm{~Hz}, \mathrm{H}-10), 7.48$ (dt, $J=7.2,1.2 \mathrm{~Hz}, \mathrm{H}-9), 7.32(\mathrm{dt}, J=7.2$, $1.2 \mathrm{~Hz}, \mathrm{H}-8), 7.18$ (d, $J=8.4 \mathrm{~Hz}, \mathrm{H}-5)$ ppm. ${ }^{13} \mathrm{C}$ NMR $(100.6 \mathrm{MHz}$, acetone- $\left.d_{6}\right): \delta 164.02$ (CO ester); 156.87 (C-3), 155.59 (C-4a), 144.72 (C-1), 141.00 (C-10a), 137.91 (C-6b), 127.54 (C-6), 126.65 (C-9), 123.54 (C-10b), 121.25 (C-8), 120.78 (C-7), 120.24 (C-6a), 116.66 (C-2), 112.28 (C-10), 108.30 (C-5), 104.42 (C-4b) ppm. Anal. calcd for $\mathrm{C}_{18} \mathrm{H}_{13} \mathrm{NO}_{4} \cdot 1 / 2 \mathrm{H}_{2} \mathrm{O}$ : C, $68.35 ; \mathrm{H}, 4.46 ; \mathrm{N}, 4.42$; found: $\mathrm{C}$, 68.49; H, 4.69; N, 4.14.

\subsubsection{3,11-Dihydro-3-oxopyrano[3,2-a]carbazole-2-carboxylic acid (6)}

To a solution of the above ester $5(0.137 \mathrm{~g}, 0.45 \mathrm{mmol})$ in hot EtOH $(40 \mathrm{~mL})$, aq $\mathrm{NaOH}(1 \mathrm{M})(1.34 \mathrm{~mL}, 1.34 \mathrm{mmol})$ was added and the mixture stirred at $60^{\circ} \mathrm{C}$ for $4 \mathrm{~h}$. After removal of the EtOH, a solid was obtained which dissolved after addition of water; this solution was cooled and acidified with aq $\mathrm{HCl}(10 \%)$. A brown solid separated which was filtered and dried $(0.122 \mathrm{~g}, 0.43 \mathrm{mmol}, 96 \%)$. Mp 312-315 ${ }^{\circ} \mathrm{C}$. ${ }^{1} \mathrm{H}$ NMR (400 MHz, DMSO-d $d_{6}$ ): $\delta$ 13.90-13.00 (very br, s, OH), 11.48 (br s, NH), $9.00(s, \mathrm{H}-1), 8.56-8.53(\mathrm{~m}, \mathrm{H}-$ 7), $8.33(\mathrm{~d}, J=8.0 \mathrm{~Hz}, \mathrm{H}-6), 8.17-8.13(\mathrm{~m}, \mathrm{H}-8$ or $\mathrm{H}-9$ or $\mathrm{H}-10)$, 7.57-7.51 ( $\mathrm{m}, \mathrm{H}-8$ and/or H-9 and/or H-10), 7.07 (d, $J=8.8 \mathrm{~Hz}, \mathrm{H}-$ 5) ppm. ${ }^{13} \mathrm{C}$ NMR (100.6 MHz, DMSO-d $\left.d_{6}\right): \delta 164.77$ (CO acid); 160.59 (C-3), 157.58 (C-4a), 139.68 (C-1), 137.30 (C-10a), 136.73 (C-6b), 129.13 (C-6), 126.50 (C-8, C-9) or C-10), 126.29 (C-10b), 126.09 (C-8 or C-9 or C-10), 120.67 (C-8 and/or C-9 and/or C-10), 119.33 (C-2), 116.74 (C-7), 114.40 (C-6a), 111.79 (C-5), 106.03 (C-4b) ppm. HR-ESI-MS: calcd for $\mathrm{C}_{16} \mathrm{H}_{10} \mathrm{NO}_{4}{ }^{+}(\mathrm{M}+1)^{+} \mathrm{m} / \mathrm{z}$ 280.06043; found: 280.06047. Anal. calcd for $\mathrm{C}_{16} \mathrm{H}_{9} \mathrm{NO}_{4}{ }_{1 / 4} \mathrm{H}_{2} \mathrm{O}$ : C, 67.72 ; H, 3.37; N, 4.94; found: C, 67.90; H, 3.10; N, 4.84.

\subsection{Tumor cell growth assay}

The compounds were evaluated for their antiproliferative effect on human cancer cell lines MDA MB231 (breast adenocarcinoma), HeLa (cervix adenocarcinoma) and TCC-SUP (bladder transitional cell carcinoma). The MDA MB231 epithelial cell line was established from a pleural effusion obtained from a 51-year-old female patient with breast cancer. The HeLa cell line was established from the epithelioid cervix carcinoma of a 31-year-old woman; later diagnosis changed to adenocarcinoma. The TCC-SUP cell line was 
established from a tumor specimen resected from the urinary bladder transitional cell carcinoma (undifferentiated, grade IV) of a 67 -year-old woman. All the cell lines were kindly provided by IPATIMUP (Portugal). The cells were maintained in an incubator with a $5 \% \mathrm{CO}_{2}$ atmosphere and at $37{ }^{\circ} \mathrm{C}$. The culture medium used was the Dulbecco's modified Eagle medium (DMEM) $\left(\mathrm{GIBCO}^{\circledR}\right.$, Invitrogen, Barcelona, Spain) supplemented with $10 \%$ of Fetal Bovine Serum (FBS) $\left(\right.$ GIBCO $^{\circledR}$, Invitrogen, Barcelona, Spain) (except for TCC-SUP cell line for which $15 \%$ FBS was used) and $1 \%$ of penicillin/streptomycin (Invitrogen, Barcelona, Spain).

\subsubsection{Cell viability}

Cells were exposed to five concentrations of compounds starting from a maximum concentration of $75 \mu \mathrm{M}$. Compounds, prepared in dimethyl sulfoxide (DMSO), were freshly diluted with cell culture medium just prior the assays. Final concentrations of DMSO did not interfere with the cell lines growth. The cell viability was determined using the MTS [3-(4,5-dimethylthiazol-2-yl)-5-(3carboxymethoxyphenyl)-2-(4-sulfophenyl)-2H-tetrazolium] method. A commercial kit was used according to the manufacturer instructions (Promega, PROM G35800001, Lisbon, Portugal). In these experiments, $100 \mu \mathrm{L}$ of cell suspension was added to each well of a 96-well plate. Additionally, control wells were included consisting of DMEM medium and the compounds prepared in DMSO at the concentrations under study. When a cell concentration of $1 \times 10^{4}$ cells $/ \mathrm{mL}$ was obtained, adequate volumes of the compounds solutions were added to the wells and incubated for 48 h. Afterwards, $20 \mu \mathrm{L}$ of the CellTitter 96 AQueous One Solution Cell Proliferation Assay reagent (MTS) was added to each well and left in the incubator $\left(37^{\circ} \mathrm{C}, 5 \% \mathrm{CO}_{2}\right)$ for $2 \mathrm{~h}$ after which the cell viability was quantified by recording the absorbance at $490 \mathrm{~nm}$. For each test compound and for each cell line a dose-response curve was generated and the growth inhibition of $50 \%$ (GI50), corresponding to the concentration of compound that inhibits $50 \%$ of the cell growth was determined. The results are expressed as percentage of viable cells compared to the control and represent an average of 3 independent cultures with 4 wells per concentration in each experiment.

\subsection{Molecular docking}

All the compounds were studied using the molecular docking software AutoDock ${ }^{57}$ and the vsLab plug-in. ${ }^{58}$ The structure of the receptor was built from the PDB structure $1 \mathrm{Z10}$ containing the Human Microsomal P450 2A6. The ligands were built with GaussView, protonated at physiological $\mathrm{pH}$ and optimized with gaussian09 (Hartree-Fock/6-31G(d)). In the docking process we used the Lamarckian genetic algorithm (LGA). The number of generations, energy evaluations, and docking runs were set to 370,000 , $1,500,000$, and 50 , respectively. The types of atomic charges were taken as Kollman for the receptor. The charges of the ligands are the Merz-Kollman type of charges that were calculated using the Gaussian software. The final solutions were retrieved from the molecular docking process according to the criteria of interacting energy.

\section{Acknowledgements}

To the Foundation for the Science and Technology (FCT, Portugal) for financial support to the NMR portuguese network (PTNMR, Bruker Avance III 400-Univ. Minho). FCT and FEDER (European Fund for Regional Development)-COMPETE-QREN-EU for financial support to the Research Centre, CQ/UM [PEst-C/QUI/ UI0686/2011 (FCOMP-01-0124-FEDER-022716)], (Pest-C/EQB/ LA0006/2011) and the PhD grant to C.S.F. (SFRH/BD/48636/2008). The authors also acknowledge the Institute of Molecular Pathology and Immunology of the University of Porto (IPATIMUP, Porto, Portugal) for kindly providing the breast cancer cell line used in this work.

\section{References and notes}

1. Bourgaud, F.; Hehn, A.; Larbat, R.; Doerper, S.; Gontier, E.; Kellner, S.; Matern, U. Phytochem. Rev. 2006, 5, 293.

2. Chen, C.-Y.; Sun, J.-G.; Liu, F.-Y.; Fung, K.-P.; Wu, P.; Huang, Z.-Z. Tetrahedron 2012, 68, 2598

3. Gambari, R.; Lampronti, I.; Bianchi, N.; Zuccato, C.; Viola, G.; Vedaldi, D.; Dall'Acqua, F. Top. Heterocycl. Chem. 2007, 9, 265.

4. Ishikawa, A.; Kuma, T.; Sasaki, H.; Sasaki, N.; Ozeki, Y.; Kobayashi, N.; Kitamura, Y. Plant Cell Rep. 2009, 28, 257.

5. Adisen, E.; Karaca, F.; Oztas, M.; Gurer, M. A. Clin. Exp. Dermatol. 2008, 33, 344.

6. Grimes, P. E. Clin. Dermatol. 1997, 15, 921.

7. Hovest, M. G.; Krieg, T.; Hermann, G. Exp. Dermatol. 2011, 20, 883.

8. Israel, M.; Schwartz, L. Biomed. Res. 2011, 22, 132.

9. Olguín-Reyes, S.; Camacho-Carranza, R.; Hernández-Ojeda, S.; Elinos-Baez, M. Espinosa-Aguirre, J. J. Food Chem. Toxicol. 2012, 50, 3094.

10. Honigsmann, H.; Brenner, W.; Rauschmeier, W.; Konrad, K.; Wolff, K. J. Am. Acad. Dermatol. 1984, 10, 238.

11. Querfeld, C.; Rosen, S. T.; Kuzel, T. M.; Kirby, K. A.; Roenigk, H. H.; Prinz, B. M.; Guitart, J. Arch. Dermatol. 2005, 141, 305.

12. Teulings, H. E.; Overkamp, M.; Ceylan, E.; Nieuweboer-Krobotova, L.; Bos, J. D.; Nijsten, T.; Wolkerstorfer, A. W.; Luiten, R. M.; Van der Veen, J. P. W. Br. J. Dermatol. 2013, 168, 162

13. Wang, X.; Lou, Y.-J.; Wang, M.-X.; Shi, Y.-W.; Xu, H.-X.; Kong, L.-D. Toxicol. Lett. 2012, 209, 67.

14. Strauss, U.; Wissel, K.; Jung, S.; Wulff, H.; Hansel, W.; Zhu, J.; Rolfs, A.; Mix, E. Immunopharmacology 2000, 48, 51.

15. Hafez, O. M.; Amin, K. M.; Abdel-Latif, N. A.; Mohamed, T. K.; Ahmed, E. Y.; Maher, T. Eur. J. Med. Chem. 2009, 44, 2967.

16. Francisco, C. S.; Rodrigues, L. R.; Cerqueira, N. M. F. S. A.; Oliveira-Campos, A. M F.; Rodrigues, L. M. Eur. J. Med. Chem. 2012, 47, 370.

17. Kawaii, S.; Tomono, Y.; Ogawa, K.; Sugiura, M.; Yano, M.; Yoshizawa, Y. Anticancer Res. 2001, 21, 917.

18. Kawase, M.; Sakagami, H.; Motohashi, N.; Hauer, H.; Chatterjee, S. S.; Spengler, G.; Vigyikanne, A. V.; Molnar, A.; Molnar, J. In Vivo 2005, 19, 705.

19. Lambertini, E.; Piva, R.; Mahmud, T. H. K.; Lampronti, I.; Bianchi, N.; Borgatti, M.; Gambari, R. Int. J. Oncol. 2004, 24, 419.

20. Leite, V. C.; Santos, R. F.; Chen, L. C.; Guillo, L. A. J. Photochem. Photobiol., B 2004 76, 49.

21. Panno, M. L.; Giordano, F.; Rizza, P.; Pellegrino, M.; Zito, D.; Giordano, C.; Mauro, L.; Catalano, S.; Aquila, S.; Sisci, D.; De Amicis, F.; Vivacqua, A.; Fuqua, S. W. A.; Ando, S. Breast Cancer Res. Treat. 2012, 136, 443.

22. Scaffidi, J. P.; Gregas, M. K.; Lauly, B.; Zhang, Y.; Vo-Dinh, T. ACS Nano 2011, 5, 4679.

23. Yang, X. W.; Xu, B.; Ran, F. X.; Wang, R. G.; Wu, J.; Cui, J. R. J. Chin. Intern. Med. 2007, 5, 56.

24. Wang, Y.; Hong, C.; Zhou, C.; Xu, D.; Qu, H.-b. Evid. Based Complement. Altern. Med. 2011, 2011, 1 .

25. Deans, A. J.; West, S. C. Nat. Rev. Cancer 2011, 11, 467.

26. Kleiner, H. E.; Vulimiri, S. V.; Reed, M. J.; Uberecken, A.; DiGiovanni, J. Chem Res. Toxicol. 2002, 15, 226.

27. Fujii-Kuriyama, Y.; Kawajiri, K. Proc. Jpn. Acad. Ser., B, Phys. Biol. Sci. 2010, 86, 40

28. Guengerich, F. P. Arch. Biochem. Biophys. 2011, 507, 1.

29. Rendic, S. Drug Metab. Rev. 2002, 34, 83.

30. Rodriguez-Fragoso, L.; Martinez-Arismendi, J. L.; Orozco-Bustos, D.; Reyes Esparza, J.; Torres, E.; Burchiel, S. W. J. Food Sci. 2011, 76, 112.

31. Marumoto, S.; Oda, Y.; Miyazawa, M. Environ. Mol. Mutagen. 2011, 52, 646.

32. Koenigs, L. L.; Trager, W. F. Biochemistry 1998, 37, 13184.

33. Baumgart, A.; Schmidt, M.; Schmitz, H.-J.; Schrenk, D. Biochem. Pharmacol. 2005, 69, 657

34. Kleiner, H. E.; Xia, X.; Sonoda, J.; Zhang, J.; Pontius, E.; Abey, J.; Evans, R. M.; Moore, D. D.; DiGiovanni, J. Toxicol. Appl. Pharmacol. 2008, 232, 337.

35. Koenigs, L.; Peter, R.; Thompson, S.; Rettie, A.; Trager, W. Drug Metab. Dispos. 1997, 25, 1407

36. Ho, P. C.; Saville, D. J.; Wanwimolruk, S. J. Pharm. Pharm. Sci. 2001, 4, 217.

37. Bariamis, S. E.; Marin, M.; Athanassopoulos, C. M.; Kontogiorgis, C.; Tsimali, Z.; Papaioannou, D.; Sindona, G.; Romeo, G.; Avgoustakis, K.; Hadjipavlou-Litina, D. Eur. J. Med. Chem. 2013, 60, 155.

38. Santana, L.; Uriarte, E.; Roleira, F.; Milhazes, N.; Borges, F. Curr. Med. Chem. 2004, 11, 3239.

39. Chilin, A.; Marzano, C.; Guiotto, A.; Manzini, P.; Baccichetti, F.; Carlassare, F.; Bordin, F. J. Med. Chem. 1999, 42, 2936.

40. Mobilio, S.; Tondelli, L.; Capobianco, M.; Gia, O. Photochem. Photobiol. 1995, 61, 113.

41. (a) Oliveira, A. M. A. G.; Raposo, M. M. M.; Oliveira-Campos, A. M. F.; Griffiths, J.; Machado, A. E. H. Helv. Chim. Acta 2003, 86, 2900; (b) Oliveira, A. M. A. G.; Raposo, M. M. M.; Oliveira-Campos, A. M. F.; Machado, A. E. H.; Puapairoj, P.; Pedro, M.; Nascimento, M. S. J.; Portela, C.; Afonso, C.; Pinto, M. Eur. J. Med. Chem. 2006, 41, 367; (c) Oliveira, A. M. A. G.; Oliveira-Campos, A. M. F.; Rodrigues, L. M.; Raposo, M. M. M.; Machado, A. E. H.; Nascimento, M. S. J.; Nazareth, N.; Pinto, M. Chem. Biodivers. 2007, 4, 980. 
42. Farag, N. A. H. Eur. J. Med. Chem. 2009, 44, 18.

43. Chaya, N.; Terauchi, K.; Yamagata, Y.; Kinjo, J.; Okabe, H. Biol. Pharm. Bull. 2004 27, 1312.

44. Setzer, W. N.; Setzer, M. C.; Schmidt, J. M.; Moriarity, D. M.; Vogler, B.; Reeb, S.; Holmes, A. M. Haber, W. A. Planta Med 2000, 66, 493.

45. Zhou, S.-F.; Liu, J.-P.; Chowbay, B. Drug Metab. Rev. 2009, 41, 89-295.

46. Lamb, D. C.; Waterman, M. R.; Kelly, S. L.; Guengerich, F. P. Curr. Opin Biotechnol. 2007, 18, 504.

47. Gillam, E. M. J.; Notley, L. M.; Cai, H. L.; De Voss, J. J.; Guengerich, F. P. Biochemistry 2000, 39, 13817.

48. Pelkonen, O.; Rautio, A.; Raunio, H.; Pasanen, M. Toxicology 2000, 144, 139.

49. Panno, M. L.; Giordanno, F.; Palma, M. G.; Bartella, V; Rago, V.; Maggiolini, M.; Sisci, D.; Lanzino, M.; Amicis, F.; Ando, S. Curr. Cancer Drug Targets 2009, 9, 469.

50. Zonneveld, I. M.; Witkamp, L.; Bossuyt, P. M. M.; Meinardi, M. M. H. M.; Bos, J. D. J. Eur. Acad. Dermatol. 1997, 9, 232.
51. Fujioka, T.; Furumi, K.; Fujii, H.; Okabe, H.; Mihashi, K.; Nakano, Y.; Matsunaga, M.; Mori, M. Chem. Pharm. Bull. 1999, 47, 96.

52. Gawron, A.; Glowniak, K. Planta Med. 1987, 53, 526.

53. Kim, D.; Wu, Z.; Guengerich, F. J. Biol. Chem. 2005, 280, 40319.

54. Sansen, S.; Yano, J. K.; Reynald, R. L.; Schoch, G. A.; Griffin, K. J.; Stout, C. D.; Johnson, E. F. J. Biol. Chem. 2007, 282, 14348.

55. Yano, J.; Hsu, M.; Griffin, K.; Stout, C.; Johnson, E. Nat. Struct. Mol. Biol. 2005, 12, 822.

56. Schlicht, K. E.; Berg, J. Z.; Murphy, S. E. Drug Metab. Dispos. 2009, 37, 665.

57. (a) Morris, G.; Goodsell, D.; Huey, R.; Olson, A.J. Comput. Aided Mol. Des. 1996, 10, 293; (b) Morris, G.; Goodsell, D.; Halliday, R.; Huey, R.; Hart, W.; Belew, R.; Olson, A. J. Comput. Chem. 1998, 19, 139; (c) Morris, G.; Huey, R.; Lindstrom, W.; Sanner, M. F.; Belew, R. K.; Goodsell, D. S.; Olson, A. J. Comput. Chem. 2009, 30, 2785.

58. Cerqueira, N. M. F. S. A.; Ribeiro, J.; Fernandes, P. A.; Ramos, M. J. Int. J. Quantum Chem. 2011, 111, 1208 . 